\title{
Role of Co-Working Spaces' Services in Entrepreneurs Growth in Upper Egypt: The Case of Step Co-Working Space
}

\author{
Ashraf Elsafty $^{1} \&$ Ahmed AlNawaly $^{2}$ \\ ${ }^{1}$ DBA., MBA., BSc., Adjunct Assistant Professor, ESLSCA Business School - Egypt Branch, Egypt \\ ${ }^{2}$ Step Co-Working Space, Founder/CEO, Assuit, Egypt \\ Correspondence: Ashraf Saeed Elsafty, DBA., MBA., BSc., Adjunct Assistant Professor, ESLSCA Business School - \\ Egypt Branch, Egypt. E-mail: ashraf@ashrafelsafty.com
}

Received: June 8, 2020

doi:10.11114/bms.v6i2.4898
Accepted: June 24, 2020

Online Published: June 29, 2020

URL: https://doi.org/10.11114/bms.v6i2.4898

\begin{abstract}
Co-working spaces are a new concept in Upper Egypt; Step co-working space is the first co-working space in Assiut governorate. Through co-working spaces services and facilities, this paper developed a new operationalization of the entrepreneurs' growth. This research design resulting conceptual framework proposes that certain combinations of cost-sharing concepts, entrepreneurial awareness, NGO support, Mentoring, and Networking activities would increase the expectation of challenging entrepreneurial growth in Upper Egypt.

A survey of unstructured interview and questionnaire used two data collection methods as a research instrument and was applied to the owner managers of Egyptian enterprises. The purpose of this paper is to investigate the relationship between entrepreneurs' growth expectations and cost sharing, awareness, NGOs support, Mentoring, Networking, gender, facilities, and unemployment in Upper Egypt.
\end{abstract}

Keywords: co-working spaces', entrepreneurs' growth, entrepreneurs' awareness entrepreneurs' expectations, services, upper Egypt

\section{Introduction}

Middle East and North Africa - MENA region witnessed a very fast transformation in business style during last decade, jobs and work nature and the ongoing technical and innovation changing started to formulate an new types of jobs and created a trend of decentralized work (Alnawaly, 2019). Technology enables work that is more flexible, more people started to work in un-traditional organizations offices, many people are choosing to work remotely with more flexibility (Al-Nawaly, 2019).

The main goal of the paper is to investigate the extent to which entrepreneurs' growth are related to entrepreneurial awareness. As this will be beneficial for the development of both business entrepreneurial growth and to understand the significance of the role of the awareness supporting such growth. This aim tested using several hypothetical statements with focus on testing the hypothetical relation between entrepreneurs' growth and awareness. Using descriptive research methodology, testing the relation of model variables, with both unstructured interviews and structured questionnaire, within natural environment for variables as a field study in a non-contrived setting with no interference.

Technology transferring also led entrepreneurs and freelancers to show up, may be it was relatively late in Upper Egypt but it happened especially last decade, many people started to launch their own businesses, which was another motive for co-working spaces to appear. The concept of co-working space developed over the last three decades, because of fast changing and technology transformation, but as normal for any new concept and technology transferring, urban suffer from delay of delivering such ideas, so co-working spaces first introduction to Upper Egypt was in 2015 in Assiut through Step co-working space (Egyptinnovate, 2019). 


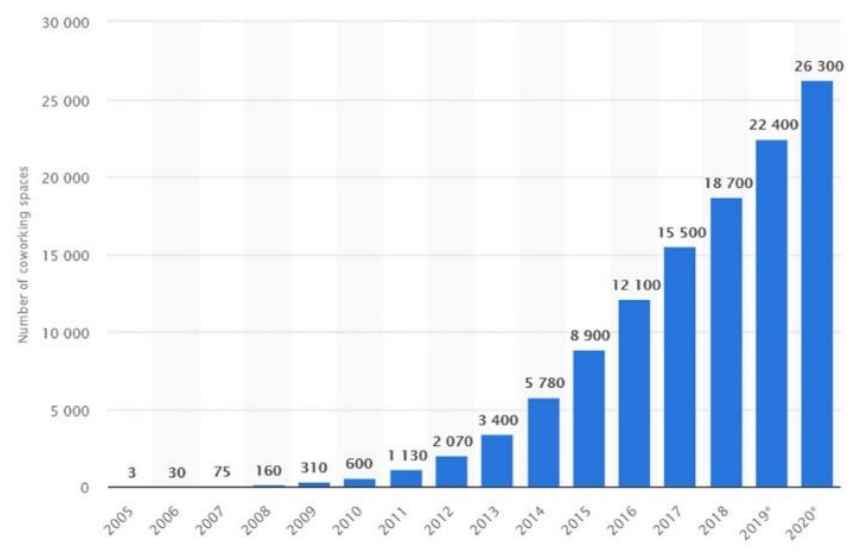

Figure 1. Number of co-working spaces worldwide from 2005 to 2020 (Statista, 2019)

As per Nabil (2018) it is not precise that the number of co-working spaces in Egypt, according to Egypt innovate website there are ninety one co-working spaces in Egypt as of April 2017. Only eighth of them in Upper Egypt, however it highlighted an increase in number of co-working spaces by 33.7 percent than early 2016 (Egyptinnovate, 2019). According to Egypt innovate there is another increase in co-working spaces number in 2019, reaching 137 co-working spaces in Egypt (Egyptinnovate, 2019).

"While a gender gap persists in many regions of the world, there are five economies in the sample where women participate at levels equal to or higher than those of men" (J. Kelley, et al., 2017). "None of these economies is at the innovation-driven stage of development, where on average women start at 60\% the rate of men" (J. Kelley, et al., 2017). Egypt has a huge gap relatively with the rest of countries introduced by GEM entrepreneurial report (GEM, 2019).

As per Elsafty (2018)(2019) figure 2, proposing the business anatomy analysis using his developed model titled The 9 Elements Model as a Business Anatomy model shown at figure 2, to analyze and define a business research problem, clearly presented online (Elsafty, DrAshrafElsafty Channel, 2020) and the recent two applications published using the 9 elements model (Elsafty, El Sayad, \& Shaaban, A Business Analysis Perspective for Engineering Education in Egypt, 2020) (Elsafty, Elsayed, \& Shaaban, Educating Engineering Students in Egypt: Recommendations for Improvement, 2020) to conduct a good and effective research, there are nine elements should be covered to determine the business anatomy of the company, which will be introduced in this business overview section. The nine elements contribute in understanding all business functions and management function and the integration between each one and other (Elsafty, business research methodologies, 2019).

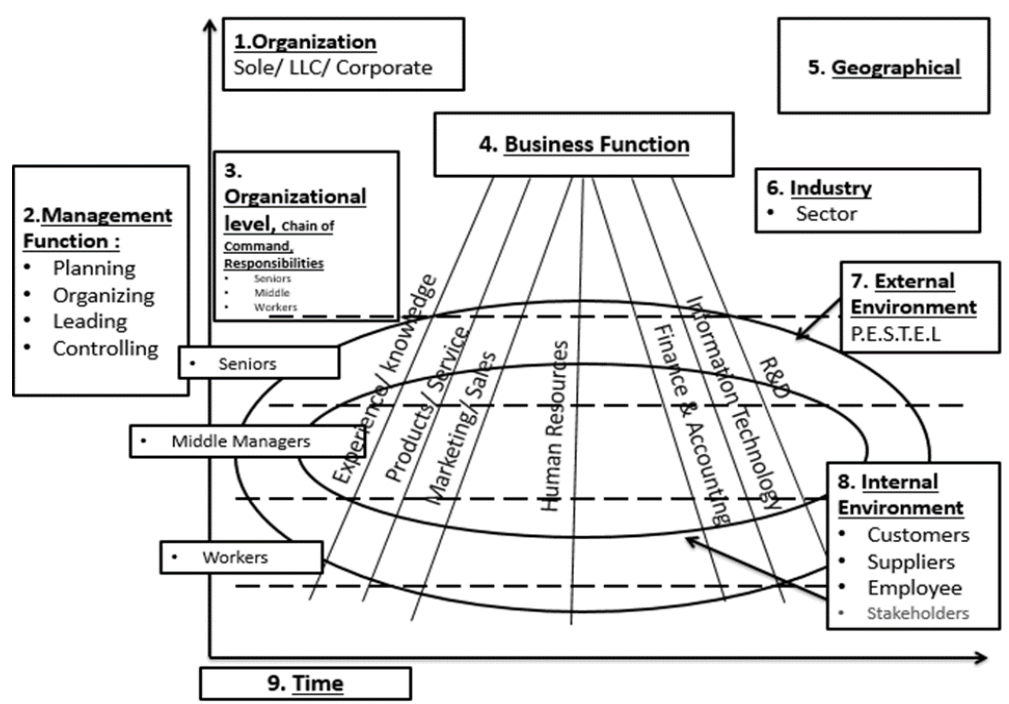

Figure 2. Business Anatomy: The 9 Elements Model Proposed by Elsafty (2018) 
Step co-working space is a sole proprietorship Egyptian company, established in 2015 in Assiut. Step was the first co-working space in Upper Egypt. Step co-working has a style of work that involves a shared working environment, yet independent activity. Unlike the typical office environment, individuals from different organizations and professions generally share a co-working space (Al-Nawaly, 2019).

Step co-working space brings people from different backgrounds, it provides customers with an opportunity to work with different people with different mindset and gain a new skills, resources and ideas about solutions to their problems and if you are in Step co-working space with more professionals, you could actually come with a creative solution (Step-eg.com, 2019).

From 2015 Step started to provide its' services and activities to Upper Egypt customers, which supposed to be entrepreneurs, startups, freelances and SME's, But due to the lack of entrepreneurs and freelancers in Assiut, the largest turnout was in the category of students and researchers.

Initially, there was confusion between the workspaces and the educational centers, many customers were unaware of the existence of such services, so there was a burden on the Step co-working space to spread the concept to customers, because Step is a market leader and Step decided by launching to take these risks and burdens (Al-Nawaly, 2019). After 6 months in 2017 campaign results started to appear, the percentage of freelancers and entrepreneurs increased relative to students and researchers, so Step started to adjust its services and activities to fit to entrepreneurs needs. Now Step trying to know how exactly its services affect entrepreneurs' outcomes (Alnawaly, 2019).

Step started to sponsor and support every possible events, which related to entrepreneurship and freelancing, Step still has one headquarter until now, but step served more than 1500 freelancer, 100 start-ups, 2500 entrepreneur and more than 4000 students and researchers in Upper Egypt (Al-Nawaly, 2019).

Step top management consists of single manager, himself the owner, Ahmad Al-Nawaly founder of Step co-working space. Step has no strategic management applications, However there is a simple statements of vision and mission with one strategic goal defined which is launching the second branch as an office space in 2020 in Assiut (Alnawaly, 2019).

STEP offering a variety of classes and workshops on creative thinking, ideation techniques, problem reframing, presentation skills, project management, data visualization, and improve (Al-Nawaly, 2019).

For entrepreneurs or startups that want more hands on assistance, STEP provides consulting services and professional training programs. STEP also has facilities like open Air Work Spaces, lounge Area, communal kitchen with tea and coffee making facilities, resource library, collaborative Meeting Spaces, support Staff, delivery and Install Team and Private Offices (Step-eg.com, 2019).

For entrepreneurs, the ability to access data from anywhere with an Internet increased the ability to work from anywhere, social media spreading has also given substantial effect and the ability to recall change to groups that had none before (Hillman, 2008).

According to the World Bank's (2016) report, Egypt ranked $155^{\text {th }}$ out of 188 economies, access to capital is another hurdle, banks have historically been reluctant to extend credit to start-ups and SMEs, preferring the high-yield, big-ticket deals on offer in the corporate segment.

Recent years have seen a combination of Egypt government efforts and private sector interest start to raise in the form of an increasingly strong entrepreneurial ecosystem. (Mzali, 2016). In the "Doing Business" 2016 report Egypt was ranked among the best-performing countries in the MENA region in terms of starting businesses, with eight days to register a company, compared to 40 days 10 years ago (Mzali, 2016). "Eight-four percent of the respondents mentioned that political instability and public disorder are the main barriers to economic growth; There are good reasons to think of this answer in the context of the ongoing turmoil in Egypt since the breakout of the January revolution in 2011" (Adly, 2014).

In Assiut and Upper Egypt generally, female in most places not supposed to be active in public communities, it also depends on the education level and family culture but it still available that gender affect to the potential of entrepreneurs. For years 2018 these was the percentages of customers using STEP co-working space at figure 3: 


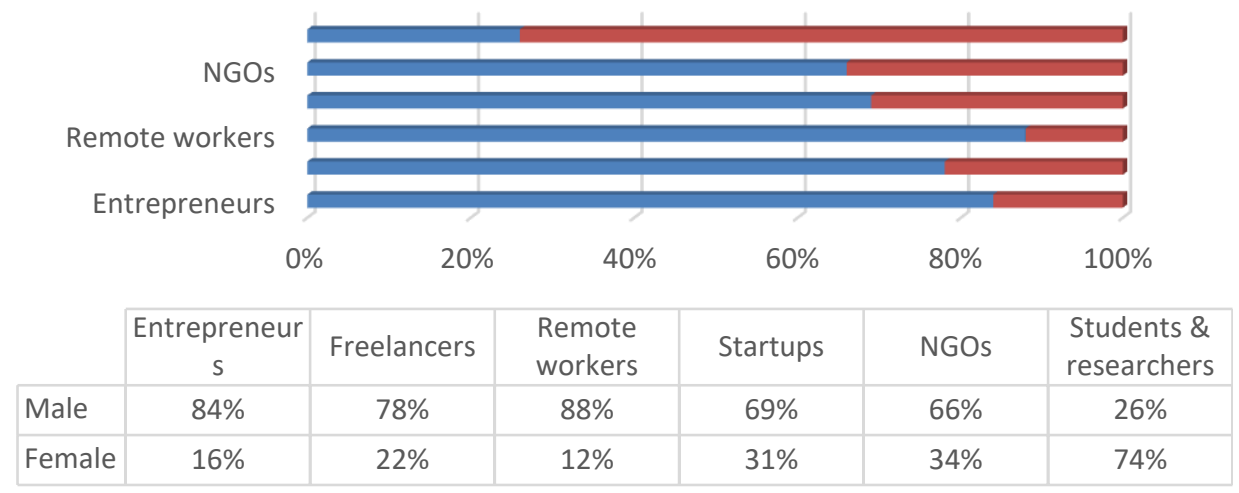

Figure 3. STEP co-working space customers' genders for year 2018, (Step co-working space, 2019)

Meeting with Hemma incubator in Assiut University representatives showed that awareness and knowledge is the most important factor to encourage entrepreneurs to start, he think also we cannot measure the responsive until spreading the entrepreneurship concept in Assiut.

Meeting with Khaled Asad the public relation at the ministry of manpower showed that high rates of unemployment in Egypt is one of the most motives to entrepreneurs to show up, it is like a Lifeline for youth and fresh graduates nowadays. In addition, there is a necessity to reduce taxes on startups especially in Upper Egypt to motivate entrepreneurs and SMEs.

\section{Literature Review}

There is two main types of co-working spaces, first the private one, which closed to one institutions or group on institutions, second public co-working spaces that is available for everyone, and as presented at figure 4 sometimes there semi public-private co-working spaces (B. Bouncken \& J. Reuschl, 2016). Customers of co-working space will be affected by the mood of co-working space interior design, facilitates and sustainability and this will change the targeted sector which will vary if its architects, artists or IT developers (B. Bouncken \& J. Reuschl, 2016).

Accessibility and opening 24/7 will directly affect the attractiveness of entrepreneurs, it may not be it all cultures, but generally it may increase attractiveness for many entrepreneurs' life styles (B. Bouncken \& J. Reuschl, 2016). Also extra services life catering, open rest areas and printing will influence customers in general and entrepreneurs especially (B. Bouncken \& J. Reuschl, 2016).

Trainings, entrepreneurship events and societal networking happening in co-working spaces can highly improve efficiency if entrepreneurs and self-employed individuals (B. Bouncken \& J. Reuschl, 2016). Societal activities in general and interiors of co-working space have its strong influence on entrepreneurs that could enhance their motives (B. Bouncken \& J. Reuschl, 2016). Working with a vary options of specialists, students, professionals and researchers like graphic designers, interior designers, programmers, managers, volunteers and students could increase social relations and resources that will give entrepreneurs a new opportunities, skills and knowledge in many fields (B. Bouncken \& J. Reuschl, 2016).

Working among this variety of professionals and mindsets could provide entrepreneurs and freelancers with a working behaviors, capabilities and satisfaction; this culture is very useful for entrepreneurs' especially new ones that gives them guidelines and future expectations with creating some sort of value adding and efficiency (B. Bouncken \& J. Reuschl, 2016). 


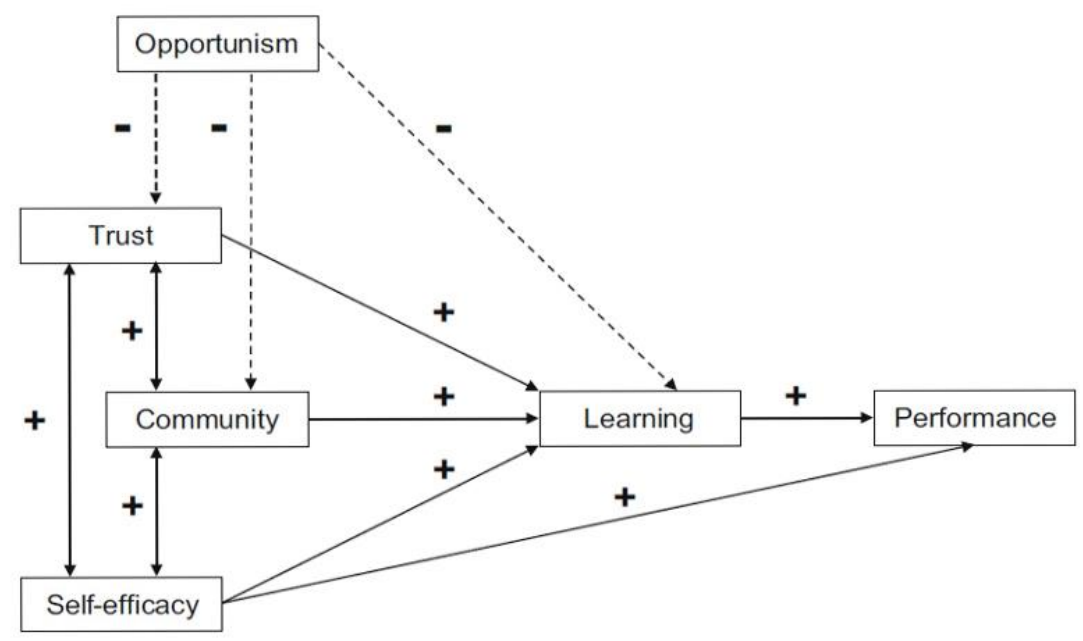

Figure 4. How a phenomenon of the sharing economy builds a novel trend for the workplace and for entrepreneurship research model (B. Bouncken \& J. Reuschl, 2016)

You can find teams' collaboration and resources sharing between coworkers that will increase their knowledge and will enhance their development (B. Bouncken \& J. Reuschl, 2016).

Gender Factor defines the actual social roles, norms, attitudes, expectations and activities rationalized to women and men, So that gender equality was one of the Millennium Development Goals and as a key to accomplish the other goals by the United Nations Population fund (Sarfaraz, Faghih, \& Majd, 2014). We can find clear gender inequality in terms of economic development as well as the rates of entrepreneurial activity; there is a significant gender gap in the entrepreneurial activity rate across the world (Allen et al. 2008)

Women engagement in entrepreneurial activity is lower in the developed areas in comparison to the developing countries (Sarfaraz, Faghih, \& Majd, 2014). Women in developed countries have more equal opportunities than she is in developing countries; different measures of gender equality increase as per average income increases (Sarfaraz, Faghih, $\&$ Majd, 2014).

There are many reasons that may make someone choose to become an entrepreneur, Necessity-based entrepreneurship occurs when someone in an economy feel they have no another job prospects, so they start a business as an substitute to unemployment; the opportunity-based entrepreneurship emerges when people realize a new business opportunity that they perceive will be successful (Lecuna, Cohen, \& Chavez, 2017) as shown at figure 5.

"The independent variables in the analyses are the motivations for startup and the attributes that entrepreneurs reported regarding themselves and their firms: self-efficacy, networking, risk-tolerance, education, and firm characteristics. Motivation was the first independent variable utilized in our model" (Lecuna, Cohen, \& Chavez, 2017).

When entrepreneurs believe they can achieve the desired results and that the outcome is primarily within their own locus of control, this is aspiring entrepreneurs, also entrepreneurial skills may serve as sources of competitive advantage that rivals find difficult to identify and imitate (Lecuna, Cohen, \& Chavez, 2017). 


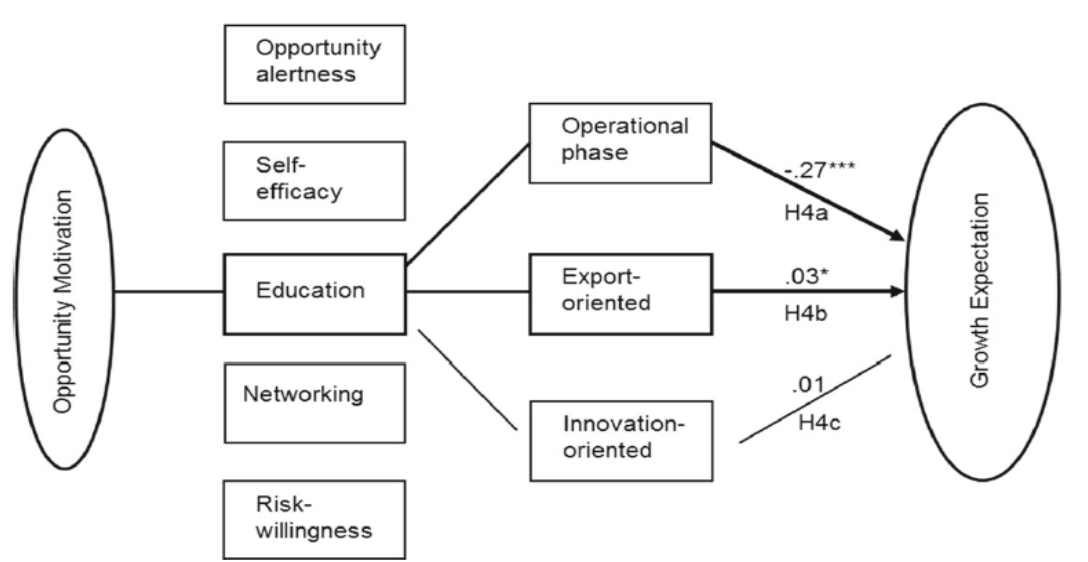

Figure 5. Triple interaction effects (Lecuna, Cohen, \& Chavez, 2017)

Research findings, particularly for developing countries, because high-growth opportunity-motivated entrepreneurship has the potential to not only create jobs but also raise people out of economic recession, make markets more innovative and competitive, and enhance countries economic growth (Lecuna, Cohen, \& Chavez, 2017).

At figure 6, Building congruent organizations considered a challenge for entrepreneurs for both today's work and tomorrow's innovation (Kearney, Hisrich, \& Roche, 2008). Entrepreneurs in the public sector and the private sector need to establish their companies in such a way that they have sufficient internal diversity in methods, structures, team to facilitate different kinds of innovation (Kearney, Hisrich, \& Roche, 2008). They also have to use relations and networking through services providers like those, that co working spaces and facilities provided to increase growth acceleration for their business (Kearney, Hisrich, \& Roche, 2008).

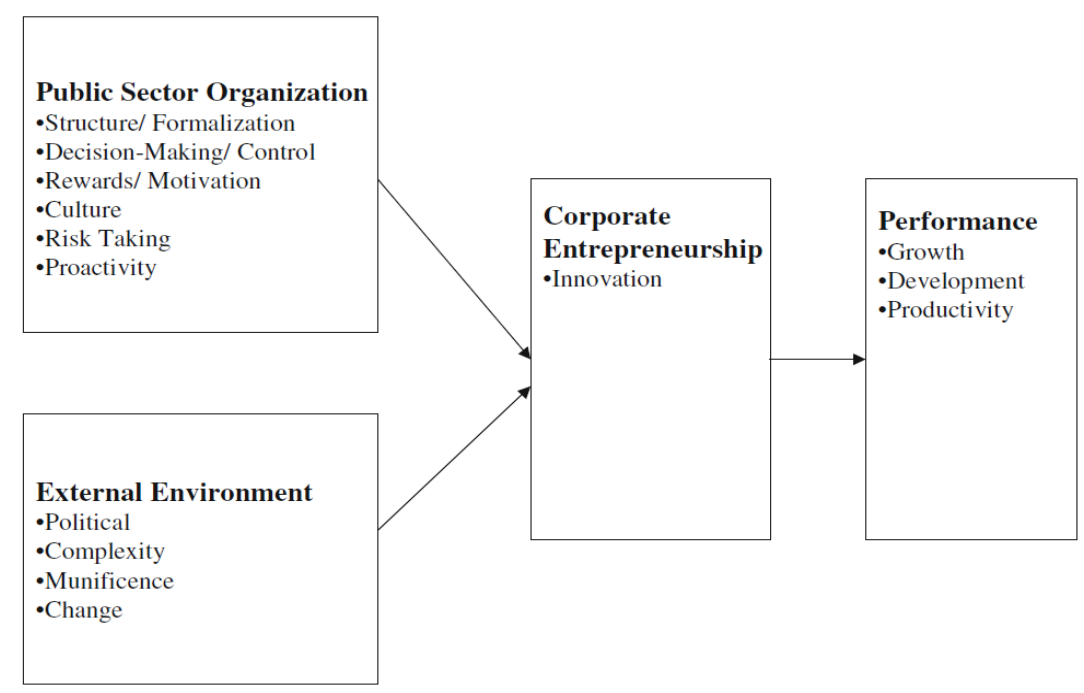

Figure 6. Model of public sector corporate entrepreneurship (Kearney, Hisrich, \& Roche, 2008)

NGOs must adapt a political, complex, munificent and changing external environment to help early-stage entrepreneurs (Kearney, Hisrich, \& Roche, 2008).

Low rates of women interaction in the economy especially in developed countries, does not seriously mean low rate of women entrepreneurship, but low women entrepreneurship rate in developing countries with a high female unemployment rates surely indicator to the low contribution of female in socio economic development (Sarfaraz, Faghih, \& Majd, 2014).

Unemployment rate may vary in its' effect from country to another, it may be logic that high unemployment rate must lead to increasing entrepreneurship rate, but it not necessarily happen in all countries, but for developing economy countries it may happen with another external factors (Cowling \& Bygrave, 2003). 
For developing economy countries especially being unemployed that is not a good thing for most people, there will not be another alternative to be self-employed, which leads to entrepreneurs' growth (Cowling \& Bygrave, 2003).

Start connecting with other now to grow professionally and personally, it is tremendously profitable and productive too, a typical co-working office not only helps you grow in your profession, it also makes you socially agile, associative and personally responsible (Butcher, 2018).

There was agreement among most of the women entrepreneurs participated in the research that social expectation from a married female about staying home with children and taking care of home and husband (Kalafatoglu \& Mendoza, 2017).

Raising the activities of social networking is opening new prospects for a diverse gathering of the crowd; also, the expanding interest of the community, there is likewise a developing chance that allows youthful business visionaries to begin their very own startups (Momen \& Sultana, 2018).

Through social networking activities, fresh business entrepreneurs can have simple access to their target audience, also they can spread their products and services among clients fast and clients' interview should be applicable too (Momen \& Sultana, 2018). Social networking activities reduce the cost and in addition decreases obstruction from the way for becoming a fecund entrepreneur (Momen \& Sultana, 2018).

Networking is any interconnectivity that includes people or systems, organizations make use of network opportunities to maintain their strategy for progress (Ezuma \& Ismail, 2017).

On the other hand, at figure 7, competence refers to knowledge, proficiency, and abilities that enable the entrepreneur to perform better in a particular situation (Ezuma \& Ismail, 2017)

So networking competence may defined as the grade of skills, proficiency, and knowledge desired by an individual to perform a relationship-building task of entrepreneurial firms (Ezuma \& Ismail, 2017).

"Entrepreneurship is a procedure of deeds of an entrepreneur, whose interest is to seek for a new thing and to exploit it into meaningful opportunities through the acceptance of risks and uncertainty that go with it" (Ezuma \& Ismail, 2017).

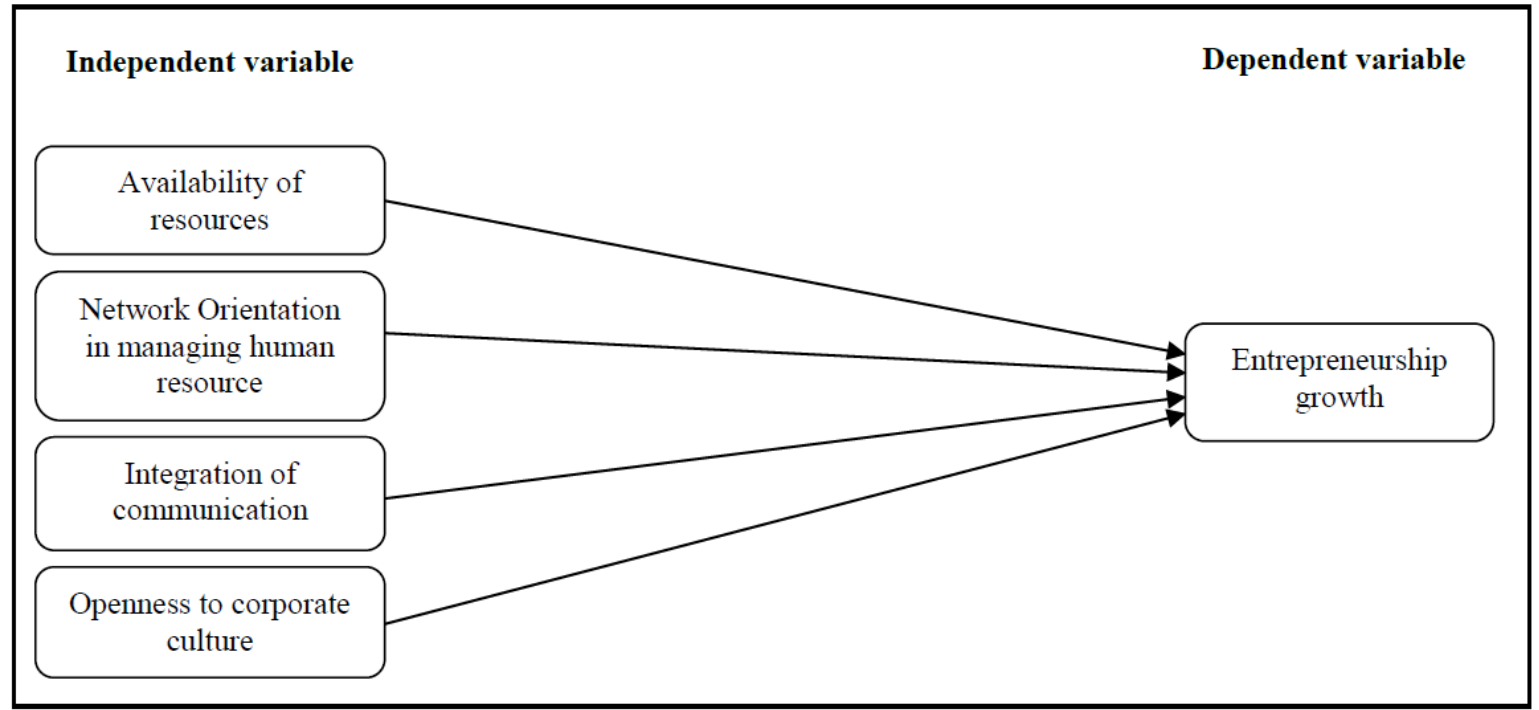

Figure 7. A framework showing the predictors of entrepreneurship growth based on network competence factors (Ezuma \& Ismail, 2017)

Growth for entrepreneurs could expedited by HRD (human resources development), this is applicable through good development of resource-based accessible through entrepreneurial training events such as on-the-job training coaching, mentoring and knowledge acquiring from other non-formal knowledge (Ezuma \& Ismail, 2017). We can say, as the standards for enhanced skill and knowledgeability, which can ultimately lead to the enhanced work environment and ultimately improving entrepreneurship growth (Ezuma \& Ismail, 2017).

Through alignment and induction of network competence factors of availability of resources, network orientation in managing entrepreneurs, integration of communication framework and organization openness in their strategic types, should drive entrepreneurs towards growth and success (Ezuma \& Ismail, 2017).This research paper framework assumed to be studied on individual bases leading to entrepreneurship growth (Ezuma \& Ismail, 2017). Thus, it is 
proposed that NGOs' that are supported by the use of the availability of resources, network tendency in managing human resources, integration of communication structure and corporate openness can embank on the desired growth track (Ezuma \& Ismail, 2017).

Instead of direct transformation of people to be entrepreneurs, figure 8 shows that it would be better to transform their attitude by enhancing their motivation factor by creative strategies that go deeper than just media and awareness campaigns (García-Rodrígueza, Gil-Soto, Ruiz-Rosa, \& Gutiérrez-Taño, 2017). These stories can be a convenience to young entrepreneurs and a vision of entrepreneurial activity in the area itself that is applicable, eligible and catchy, also help breach entrepreneurship brain exhaustion from the environment (García-Rodrígueza, Gil-Soto, Ruiz-Rosa, \& Gutiérrez-Taño, 2017).

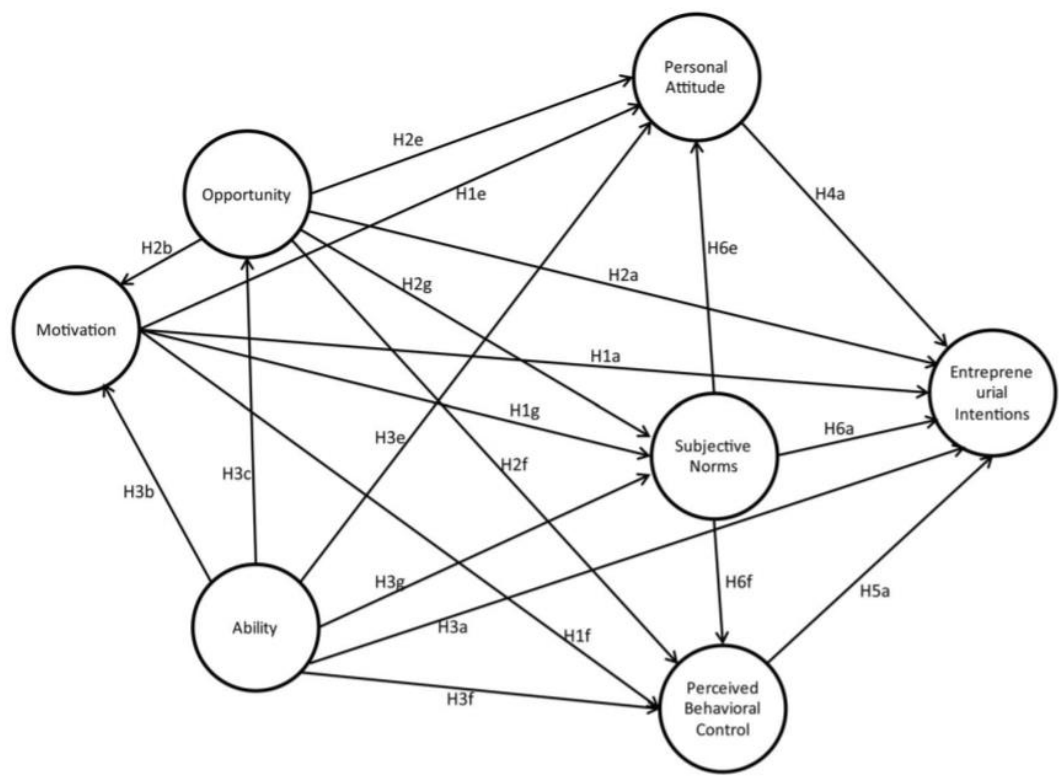

Figure 8. Estimated causal relations in structural model (García-Rodrígueza, Gil-Soto, Ruiz-Rosa, \& Gutiérrez-Taño, 2017)

Family impact on the women entrepreneurial growth expectations and this impact influence decision-making process (Venugopal, 2016). This effect may be more influencing in some developing country and closed culture countries than other developed countries (Venugopal, 2016). However, the expectation from women entrepreneurs to take care of the family has a negative effect on growth potential (Venugopal, 2016). In developed country, especially rural sectors, women is not completely dependent socially or economically, so there is obstacles facing women to be entrepreneurs, taking risks and following their dreams (Venugopal, 2016).

\section{Methodology}

Research used a quantitative research method for a descriptive purpose. Depending on models and scattered variables, these data will be analyzing using unstructured expert interviews. We have made an extensive literature review to define the current stage of knowledge regarding to the factors affect entrepreneurs' growth. Collecting data from a natural environment for variables as a field study in a non-contrived setting with no interference.

\subsection{Theoretical Framework}

\section{Figure 9 shows the theoretical framework as follows:}

Dependent variable: Entrepreneurs' growth “An entrepreneur is an individual who creates a new business, bearing most of the risks and enjoying most of the rewards" (HAYES, 2019). Entrepreneurs growth here as a dependent variable does not stipulate they will be a successful entrepreneurs or not, but it means the concept of entrepreneurial way of thinking, motive to launch a startup and finally the entrepreneurial life style (Al-Nawaly, 2019).

\section{Independent variable:}

IV1. Cost sharing: refers to the concept of using facilitates internet connection, furniture, catering, printer, supplies and tools provided by the co-working spaces but not owing them, you only share using it with other coworkers that reduce your costs of outcomes.

IV2. Awareness: refers to entrepreneurial general awareness and knowledge. 
IV3. NGOs support: refers to the role of NGOs to support fresh entrepreneurs with training and development programs, also by providing fund and rewards to fresh startups.

IV4. Mentoring: refers to the role of mentors in co-working spaces and business incubators in guiding fresh entrepreneurs to give them a better vision and to make them avoid mistakes.

IV5. Networking: refers to the networking activity happens in co-working spaces.

\section{Moderating variables:}

M1: Gender: refers to the gender differences being male or female in entrepreneurial growing.

M2: Facilities: refers to accessibility, internet connection, work-life balance services, printing, easing, and catering facilities provided by co-working spaces.

M3: Unemployment rate: refers to the amount of people workable force, which is not able to find suitable jobs for their qualifications.

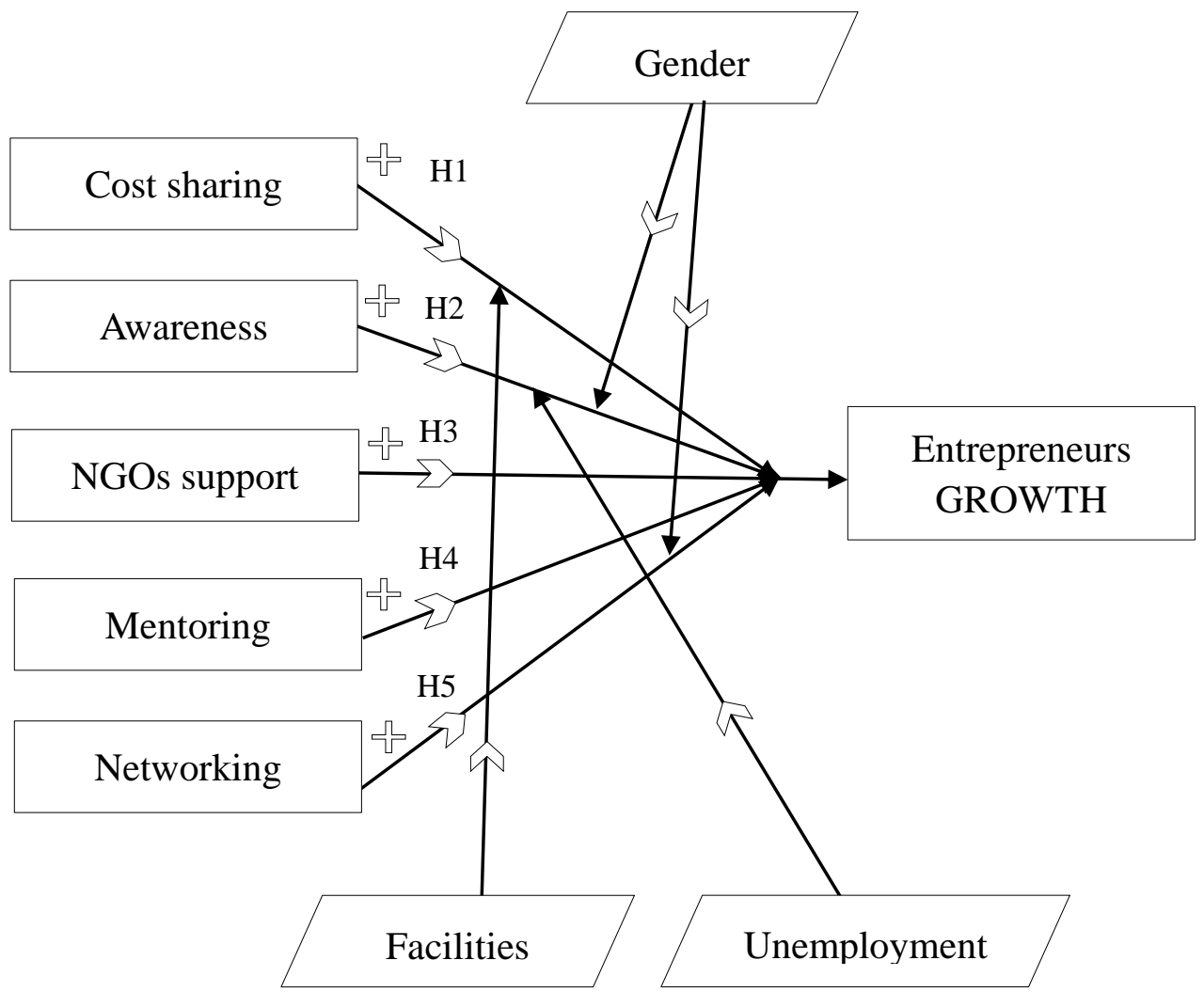

Figure 9. Proposed Research Theoretical Framework

\subsection{Hypothetical Statement}

Ha1: There is a positive relationship between NGOs support and entrepreneurs' growth.

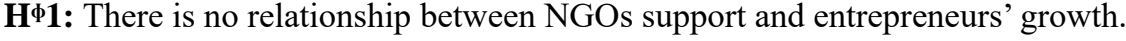

Ha2: There is a positive relationship between cost sharing and entrepreneurs' growth.

$\mathbf{H} \mathbf{\phi}$ 2: There is no relationship between cost sharing and entrepreneurs' growth.

Ha3: There is a positive relationship between mentoring and entrepreneurs' growth.

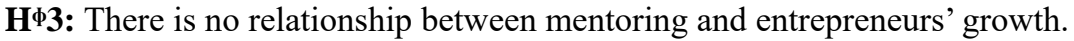

Ha4: There is a positive relationship between networking and entrepreneurs' growth.

H 4: There is no relationship between networking and entrepreneurs' growth.

Ha5: There is a positive relationship between awareness and entrepreneurs' growth.

H'5: There is no relationship between awareness and entrepreneurs' growth.

Ha6: There is a positive relationship between facilities and entrepreneurs' growth. 
H'6: There is no relationship between facilities and entrepreneurs' growth.

Ha7: The Unemployment influence the relationship between awareness and entrepreneurs' growth.

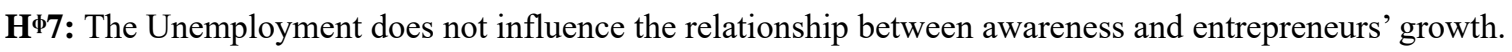

Ha8: The Gender influence the relationship between Networking and entrepreneurs' growth.

H'8: The Gender does not influence the relationship between Networking and entrepreneurs' growth.

Ha9: The Gender influence the relationship between awareness and entrepreneurs' growth.

H'9: The Gender does not influence the relationship between awareness and entrepreneurs' growth.

\subsection{Data Collection}

The primary data collected through using a human interactive source with experts using 'Unstructured Interviews' representing different types (entrepreneurs, mentors and co-working space customers). Starting with using unstructured interview method to ensure about the variables and finally will use the 'Questionnaire' method by two different ways:

A quantitative research method for a hypothesis testing, exploratory purpose. Depending on models and scattered variables, these data will be analyzing using expert interviews.

\subsection{Unstructured Interview}

For the Unstructured Interview with experts, the topics will be introduced for the discussion and allow respondents to being talking about their beliefs concerns and views to investigate the following objectives, covering all research variables stated at the theoretical framework (hypothetical statements):

1. The role of NGOs support on entrepreneurs' growth.

2. The role of cost sharing concept on entrepreneurs' growth.

3. The role of networking activities on entrepreneurs' growth.

4. The role of mentoring on entrepreneurs' growth.

5. The role of entrepreneurial awareness on entrepreneurs' growth.

6. The role of facilities on entrepreneurs' growth.

7. Does unemployment rate affect entrepreneurial awareness?

8. Does Gender concept affect the networking activity?

9. Does Gender concept affect entrepreneurial awareness?

Research used the above 9 questions as open-ended questions with each expert within the 'Unstructured Interviews' detailed in Appendix A\&B.

\subsection{Questionnaire Development}

After completion of the experts using 'Unstructured Interviews', based on the results, a questionnaire generated, with questions to validate the variables, the design of questionnaire included a measurement scale as interval scale to measure the relation between the research variables (dependent variable with the independent variables with the answers of the experts).

\subsection{Terms Definition}

Population will be from the following organizations:

- $\quad$ TIEC (Technology Innovation \& Entrepreneurship Center) Business Incubator.

- Assiut university business incubator (Hemma).

- STEP co-working space Founder and managers.

- Four recent opened co-working spaces in Assiut.

- Silicon Waha New Assiut smart village Co-coordinators.

\subsection{Sampling}

In this paper, I target some organizations, which is the most suitable to these issues, the number of total employees will be difficult to determine accurately, but because I need just top management staff, we will not have many troubles in not defining the total population of employees accurately.

For the Questionnaire, sample size calculated based on the population of 300, with confidence level of 95\%, error of $10 \%$, 
with a recommended sample size of 37 (Sample size calculator, 2019). While for the Expert Unstructured Interviews calculated based on the population of 120 , with confidence level of $95 \%$, error of $10 \%$, with a recommended sample size of 4 (Sample size calculator, 2019). Using a sampling design for both Expert Unstructured Interviews and Questionnaire as a Nonprobability sampling, with sampling Criteria of Judgmental Sampling.

\section{Data Analysis}

Descriptive techniques used such as frequency tables, histograms and ranking tables for mean values to describe the responses collected and the meaning of each question.

The first phase of data analysis was preliminary investigations to verify or enrich the proposed model via unstructured expert interviews with subject matter experts.

At the same time in the second phase, the questionnaire has done to measure the validity of each variable to ensure or decline each one of variables. The survey launched through face-to-face delivering in Silicon-Waha new Assiut campus, STEP co-working spaces front office and Assiut University from December 72019 until December 10 2019; the collected feedback was from 37 respondents.

Directly communicates with the expertise in entrepreneurship field reforming at a similar situation with the prepared questions. This will enable the research to acquire valued information during the conversation with the experts. This method ensured the quality of the obtained data and increases the response rate, also it will ensure for each variable that I asked about 5 questions if it is related to entrepreneurial growth or not, and if it is related; how could the variable affect the entrepreneurs' growth in Upper Egypt especially in Assiut.

More males (23) than females (14) have participated in the study. Ages range was; none of the respondents was below 21 , none of the respondents was above 49, and I ensured to have a different ages and genders to get wider perspective. While entrepreneurs' growth considered as a challenge in Assiut, so we can go deeper with the variable entrepreneurs' growth through the rest of variables questions and results. Results showed $89.1 \%$ of respondents strongly agree that NGOs support can be one of the factor that affect entrepreneurs' growth in Assiut. This big percentage ensures the validity of NGOs support as a variable for entrepreneurs' growth in Assiut. As for Cost sharing concept, 89.1\% of respondents strongly agree that it can be one of the factors that affect entrepreneurs' growth in Assiut. This big percentage ensures the validity of cost sharing concept as a variable for entrepreneurs' growth in Assiut. A $54.05 \%$ of respondents strongly agree that Mentoring role can be one of the factor that affect entrepreneurs' growth in Assiut, With another $40.5 \%$ Agree with the same. These percentages ensures that mentoring activity which could done through co-working spaces can play important role in entrepreneurs' growth in Assiut. According to questionnaire results, 70\% of respondents strongly agree that networking activities that happen in co-working spaces can affect entrepreneurs' growth in Assiut, with another 21.62\% Agree with the same. Therefore, we can say networking activities can play important role in entrepreneurs' growth in Assiut. With high value of $91.8 \%$ of respondents strongly agree that entrepreneurial awareness can affect entrepreneurs' growth in Assiut. This may seem logic because without knowing about entrepreneurship there is no chance to grow, so this can ensure the role of awareness in my dependent variable entrepreneurs' growth. Then $64.8 \%$ of respondents strongly agree that co-working spaces facilities can affect entrepreneurs' growth in Assiut. Another 27\% agree with the same. These results can ensure the role of co-working spaces facilities in moving entrepreneurs' growth to better rates. Unemployment affect on the relationship between awareness and entrepreneurs' growth scored the highest strongly agree percentage with $94.5 \%$ respondents. This can obviously ensure that unemployment rate can be transforming from a country problem to an opportunity with the strong entrepreneurial awareness. With low value of $56.7 \%$ of respondents strongly agree that Gender variations affect the relationship between networking activities and entrepreneurs' growth; this may be according the Upper Egypt culture that detailed in this paper introduction and business overview sections. Therefore, it can ensure the role of gender in our research.

Moreover, 54\% of respondents strongly agree that Gender variations affect the relationship between entrepreneurial awareness and entrepreneurs' growth, with another 35\% agree with the same concept. With last results from the gender role in the relationship between networking activities and entrepreneurs' growth we can definitely ensure that gender variations that came from society culture may need a lot of work to avoid its' negative effect on entrepreneurs' growth in Assiut.

\section{Conclusions}

Entrepreneurs' growth in Assiut is a challenge, a substantial part of this paper focuses on investigating the extent to which entrepreneurs' growth are related to entrepreneurial awareness. The results of our research support our prediction that awareness positively influence entrepreneurs' growth. From expert interview insight, the relationship between entrepreneurial awareness and entrepreneurs' growth expectations effected by gender concept that we mean there is a 
variation between the rates of outcomes from being a female. Surprisingly, we find no clear evidence of a relation between the NGOs support motive and entrepreneurs' growth, therefore we cleared this part on our questionnaire and expert interviews and all results ensured that there is a positive effect of NGOs support on entrepreneurs' growth expectations. Another aspect that receives attention in this paper, since it may affect entrepreneurs' growth, is mentoring activities, which we have apply through the spread of co-working spaces, incubators and business accelerator. Previous empirical studies have explored the positive relationship between cost sharing concept and entrepreneurs' growth (Momen \& Sultana, 2018), this study also tend to find a positive relationship between ease access to internet and entrepreneurs' growth, which reflect on our facilities variable definition. The impact of gender discrimination on early-stage entrepreneurial activity in low/middle-income country group might show some significance compared to the other high-income groups (Sarfaraz, Faghih, \& Majd, 2014). As per Venugopal (2016), contributes to the gender and entrepreneurship literatures in several main ways, it furthers our understanding of growth of the entrepreneurs' in the context of women entrepreneurship in the culturally diverse context. From reviewing Ezuma \& Ismail (2017) paper, we can notice the predictor variables in the framework assumed to study on individual bases leading to entrepreneurship growth. Thus, it proposed that entrepreneurs supported by the use of availability of resources, networking orientation in managing human resources, integration of communication structure and corporate openness can dike on the desired growth route, which ensure the positive relationship between Networking activities and entrepreneurs' growth.

We could not also find a clear science that ensure the effect of gender concept on the networking activity and entrepreneurs' growth. However there is many studies ensured the impact of gender variation on similar cases, so we can say that may cleared as a specific case applied on Upper Egypt and if cleared after questionnaire and interviews results.

One of the most important outcomes of this paper, that this research leveraged the proposed impact of co-working spaces facilities on the relationship between cost sharing concept and entrepreneurs' growth expectations, but after literature review there were no clear defining for the role of unemployment rate on the relationship between entrepreneurial awareness and entrepreneurs' growth. In addition, paper of Lecuna, Cohen, \& Chavez (2017) showed how the theory of planned behavior supports prediction of entrepreneurial growth in developing countries. We proposed a model that consider a vary of variables which we claimed it is the most related to co-working spaces environment to determine the context of impact on entrepreneurs' growth, also to define the drivers of entrepreneurial growth potential in Upper Egypt. The paper highlights the importance of co-working spaces services, NGOs support, Mentoring, and entrepreneurial awareness as reasons why entrepreneurs take decisions to launch their startups.

\subsection{Recommendations}

This paper finding showed that we have to highlight the role of entrepreneurial awareness campaigns; also, we still have to look deeply in the co-working spaces role in motivating individuals becoming entrepreneurs. There are some limitations of this study his study covers only the relationship between eight variables and their impact on growth. However, further studies may cover determinants of these eight concepts.

\subsection{Future Work}

In summary, our paper has pointed to a number of potential questions for future research. Like unemployment rate, and how we could transform this number from a country obstacle into entrepreneurial creative opportunity. However, we suggest that there is a major need for intensive qualitative methods, to complete and enrich the findings provided by quantitative database and experimental approaches that are able to provide insights into real processes of entrepreneurial growth.

\section{References}

(2019, February 26). Retrieved from thenational: https://www.thenational.ae/business/economy/how-egypt-became-the-fastest-growing-nation-for-start-ups-in-mena $-1.830379$

(2019). Retrieved from Egyptinnovate: https://egyptinnovate.com/en/innovation/map

$$
\text { August). }
$$

Retrieved

from

Statista:

$$
\text { https://www.statista.com/statistics/554273/number-of-coworking-spaces-worldwide/ }
$$

Abdel-Ghaffar, A. (January 2018). A stable Egypt for a stable region: Socio-economic challenges and prospects. Belgium: European Parliament's Committee on Foreign Affairs.

Adly, A. (2014). Reforming the Entrepreneurship Ecosystem in Post-Revolutionary Egypt and Tunisia. Encina Hall : Stanford University.

Alam, S. (2019). Operation director. Asyut, Egypt: Interview. 
Allen, E. E. (2008). Report on Women and Entrepreneurship. The Center for Women's Leadership at Babson College. Baruch: Global Entrepreneurship Monitor.

Alnawaly, A. (2019, October). STEP Founder. Assiut, Egypt.

Al-Nawaly, A. (2019). STEP Founder . Assiut, Egypt.

Antoncic, B., \& Hisrich, R. D. (2001). Intrapreneurship: Construct refinement and cross-cultural validation. Journal of Business Venturing, 495-527. https://doi.org/10.1016/S0883-9026(99)00054-3

Bouncken, B. R., \& Reuschl, J. A. (2016). Coworking-spaces: how a phenomenon of the sharing. Springer, 318-331.

Butcher, T. (2018). Learning everyday entrepreneurial practices through coworking. Management Learning, 327-345. https://doi.org/10.1177/1350507618757088

Cowling, M., \& Bygrave, W. D. (2003). Entrepreneurs and Unemployment: relationship between unemployment and entrepreneurship in 37 nations participating in the global entrepreneurship monitor (GEM) 2002. Frontiers of entrepreneurship research, 544-555.

Diaa, S. (2019). Community Director. Asyut, Egypt: Interview.

Elsafty, A. (2019). business research methodologies. Assiut, Egypt: Eslsca Business school.

Elsafty, A. (2020, 1 21). DrAshrafElsafty Channel. Retrieved from Youtube: https://www.youtube.com/watch?v=y-jDT2iOOhU\&list=PLKSWZdnzp8p3uFLLh2N8_d0W7ZmJDLMjW\&index $=42 \& \mathrm{t}=628 \mathrm{~s}$

Elsafty, A., El Sayad, H., \& Shaaban, I. (2020, May). A Business Analysis Perspective for Engineering Education in Egypt. Journal of Education and Training Studies. https://doi.org/10.11114/jets.v8i5.4721

Elsafty, A., Elsayed, H., \& Shaaban, I. (2020). Educating Engineering Students in Egypt: Recommendations for Improvement. International Journal of Higher Education. https://doi.org/10.5430/ijhe.v9n3p1

Ezuma, K. E., \& Ismail, M. (2017). Conceptualizing the Influence of Network Competence on Entrepreneurship Growth in Small and Medium Enterprises. Global Business and Management Research, 30-44.

FOLGER, J. (2019, July 7). Retrieved from Investopedia: https://www.investopedia.com/ask/answers/13/what-is-non-government-organization.asp

García-Rodrígueza, F. J., Gil-Soto, E., Ruiz-Rosa, I., \& Gutiérrez-Taño, D. (2017). Entrepreneurial process in peripheral regions: the role of motivation and culture. EUROPEAN PLANNING STUDIES, 2037-2056. https://doi.org/10.1080/09654313.2016.1262827

GEM. (2019). Retrieved from gemconsortium: https://www.gemconsortium.org/economy-profiles/egypt

Hamouda, A. (2019). HR specialist. Asyut: Interview.

HAYES, A. (2019, september 4). Retrieved from Investopedia: https://www.investopedia.com/terms/e/entrepreneur.asp

Hillman. (2008). 6 reasons to start coworking. https://me.mashable.com/. Retrieved from https://mashable.com/2008/11/07/reasons-to-start-coworking/

Hutchins, E. (1991). The social organization of distributed cognition.

Kelley, J. D., Baumer, S. B., Brush, C., Greene, G. P., Mahdavi, M., Majbouri, M., . . . Heavlow, R. (2017). GEM Women's Entrepreneurship 2016/2017 Report. 870 Commonwealth Avenue: The Fenway Group .

Kalafatoglu, T., \& Mendoza, X. (2017). The impact of gender and culture on networking and venture creation: An exploratory study in Turkey and MENA region. Cross Cultural \& Strategic Management, 332-349. https://doi.org/10.1108/CCSM-04-2016-0090

Kearney, C., Hisrich, R., \& Roche, F. (2008). A conceptual model of public sector corporate entrepreneurship. Int Entrep Manag J, 295-313. https://doi.org/10.1007/s11365-007-0048-x

Lecuna, A., Cohen, B., \& Chavez, R. (2017). Characteristics of high-growth entrepreneurs in Latin America. Int Entrep Manag J, 141-159. https://doi.org/10.1007/s11365-016-0402-y

Leforestier, A. (2009). The co-working space concept. Ahmedabad: Indian Institute of Management (IIMAHD).

Momen, A., \& Sultana, S. (2018). Web based Entrepreneurship via Social Networking Sites: Bangladesh Perspective. Middle East Journal of Business, 5-11. https://doi.org/10.5742/MEJB.2018.93187 
Mzali, S. (2016). Retrieved from Oxford Broup: https://oxfordbusinessgroup.com/analysis/key-consideration-environment-start-ups-and-small-businesses-improvin $\mathrm{g}$

Nabil, J. (2018, August). Retrieved from American Chamber of Commerce in Egypt: https://www.amcham.org.eg/publications/business-monthly/issues/272/August-2018/3759/capturing-the-rising-tren d-of-coworking-spaces

Nonaka, I., \& Takeuchi, H. (1995). How Japanese companies create the dynamics of innovation. https://doi.org/10.1016/0024-6301(96)81509-3

Sample size calculator. (2019). Retrieved from Creative research system: https://www.surveysystem.com/sscalc.htm

Sarfaraz, L., Faghih, N., \& Majd, A. A. (2014). The relationship between women entrepreneurship and gender equality. Journal of Global Entrepreneurship Research, 2-11. https://doi.org/10.1186/2251-7316-2-6

Shahat, M. (2015). Retrieved from Nudge Sustainability http://www.nudgesustainabilityhub.com/initiatives/2015/11/8/co-working-spaces-helps-build-entrepreneurial-susta inable-communities-in-egypt

Step coworking space. (2019, 11). Retrieved from Facebook: https://www.facebook.com/stepcoworking/

Step-eg.com. (2019). Retrieved from http://step-eg.com/loadindex.html

Uda, \& Tadashi. (2013). What is Coworking? : A Theoretical Study on the Concept of. HUSCAP. https://doi.org/10.2139/ssrn.2937194

Venugopal, V. (2016). Investigating women's intentions for entrepreneurial growth. International Journal of Gender and Entrepreneurship, 2-27. https://doi.org/10.1108/IJGE-11-2014-0043

\section{Copyrights}

Copyright for this article is retained by the author(s), with first publication rights granted to the journal.

This is an open-access article distributed under the terms and conditions of the Creative Commons Attribution license which permits unrestricted use, distribution, and reproduction in any medium, provided the original work is properly cited. 